\title{
Anti-spermatogenic and estrogenic effects of Escravos crude oil in Chinchilla rabbits
}

\author{
A.A. NGOKERE ${ }^{1}$, J.O. OKOYE ${ }^{1 *}$, E. OBI $^{2}$, S.N. IBEKAILO ${ }^{3}$, J.C. AWALU ${ }^{1}$ \\ et I. AUDU ${ }^{4}$ \\ ${ }^{I}$ Department of Medical Laboratory Science, Faculty of Health Science and Technology, Nnamdi Azikiwe \\ University, Nnewi Campus, P. M. B. 5001, Anambra State, Nigeria. \\ ${ }^{2}$ Department of Pharmacology and Therapeutics, Faculty of Basic Medicine, College of Health Science, \\ Nnamdi Azikiwe University, Nnewi Campus, Nnewi, Nigeria. \\ ${ }^{3}$ Department of Physiology, Federal University Ndufu-Alike, Ikwo, Ebonyi State, Nigeria. \\ ${ }^{4}$ Department of Medical Laboratory Services, Federal Medical Centre Gusau, Zamfara State, Nigeria. \\ ${ }^{*}$ Corresponding author; Email: judeokoye42@yahoo.com; Tel: +234-703-1119-994
}

\begin{abstract}
This study aimed at investigating the effects of Escravos crude oil on spermatogenesis in relation to serum concentrations of estradiol and total cholesterol. A total of 30 male Chinchilla rabbits within the age range of 12 to 14 weeks and weighing $1.2 \mathrm{~kg}$ to $1.45 \mathrm{~kg}$ were used in this study. The doses of $00,15,20,25$ and $30 \mathrm{mg} \mathrm{kg}^{-1}$ body weight of Escravos crude oil were orally administered to groups $\mathrm{A}, \mathrm{B}, \mathrm{C}, \mathrm{D}$ and E, respectively for 28 days. Serum concentrations of estradiol and total cholesterol were estimated using the microplate enzyme immunoassay and enzymatic end point methods, respectively. The SPSS software package (version 16) was used for the statistical analyses and results expressed in mean \pm Standard Deviation. The results showed dose dependent significant increases in estradiol $(18.32+/-6.46$ to $69.41+/-12.89 \mathrm{pg} / \mathrm{ml})$ and total cholesterol $(1.32+/-0.24$ to $2.92+/-0.34 \mathrm{mmol} / \mathrm{l})$ concentrations $(\mathrm{p}<0.05)$, and insignificant increase (p>0.05) in the relative weight of the testis $(3.80+/-0.40$ to $5.50+/-0.90 \mathrm{~g}$ ). The histology of the testes revealed decreased spermatogenic activity. The findings of this study suggest that Escravos crude oil could be a potential endocrine disruptor and anti-spermatogenic agent.
\end{abstract}

(C) 2014 International Formulae Group. All rights reserved.

Keywords: Escravos crude oil, Estradiol, Anti-Spermatogenesis, Total cholesterol, Chinchilla rabbits.

\section{INTRODUCTION}

Crude oil is believed to be a curative agent of high efficacy for gastrointestinal disturbances and antidote to poisoning, respiratory distress and convulsion (Dede et al., 2002; Eyong et al., 2004). A sample from Luawii in Ogoni (Nigeria), where there have been no oil production for four years, had 18 ppm of hydrocarbons in its water, 360 times the level allowed in drinking water in the European Union (EU) while another sample from Okpeleide, Ikwerre (Nigeria) contained 34 ppm, 680 times the EU standard (Nwilo and Badejo, 2005). Petroleum hydrocarbons have been shown to affect reproductive processes leading to reduction in sperm 
motility (Adesanya et al., 2009), reduction in testosterone levels (Otitoju et al., 2011) and testicular cancer (Delbes et al., 2006). Escravos crude oil have also been reported to induce marked lymphocytic infiltration, fibrosis, hemosiderosis and ballooning degeneration on the liver (Ngokere et al., 2014) and acute glomerulonephritis (Okoye et al., 2014a) following direct exposure.

Cholesterol is an unsaturated steroid alcohol. It functions majorly as a metabolic precursor for the biosynthesis of bile acids, and steroid hormones which include male and female sex steroids (androgens and oestrogens) and adrenal steroid hormones (aldosterones and corticosterone). The Liver, Ovaries, testes and adrenal glands synthesize these hormones using cholesterol as the main precursor (Morrissey, 2006). The three major naturally occurring estrogens in women are estrone (E1), estradiol (E2), and estriol (E3). Estradiol is the predominant estrogen during reproductive years both in terms of absolute serum levels as well as in terms of estrogenic activity. All of the different forms of estrogen are synthesized from androgens, specifically testosterone and androstenedione, by the enzyme aromatase. Furthermore, there are several other structural changes induced by estrogen in addition to other functions. A direct role of estradiol as a germ cell survival factor has been demonstrated in the human testis in vitro, where estradiol was shown to inhibit testicular apoptosis much more effectively (100- to 1000-fold) than testosterone (Pentikainen et al., 2000).

A lot of studies have been carried out on the effect of crude oil on serum testosterone level, however little or no work have been carried out to evaluate its effect on serum estradiol concentration and its precursor, cholesterol. Thus, this study aimed to investigate the effect of Escravos crude oil on spermatogenic activity in the testes of Chinchilla rabbits in relation to serum concentrations of estradiol and total cholesterol.

\section{MATERIALS AND METHODS \\ Test sample}

The Escravos blend crude oil (with reference number 863) used in this study was provided by Warri Refining and Petrochemical Company Effurun, Delta State, Nigeria. The crude oil was exposed to sunlight in shallow pans $(25 \mathrm{~cm} \times 25 \mathrm{~cm} \times 5 \mathrm{~cm})$ for 24 hours at the site of the study to allow the extremely light and volatile fractions to evaporate leaving behind the stable components. This product simulates the naturally occurring condition following spillage (Neff et al., 2000).

\section{Experimental design}

A total of 30 male Chinchilla Rabbits within the age range of 12 to 14 weeks and weighing 1.2 to $1.45 \mathrm{~kg}$ was used for this study. The animals were examined, treated for ectoparasites using Lymectin (Hebei New Century Pharmaceutical C0. Ltd) by a veterinarian and allowed to acclimatize for two weeks. The animals were divided into five groups, tagged Group A (control), B, C, $\mathrm{D}$ and $\mathrm{E}$, each containing 6 rabbits. Group B to $\mathrm{E}$ were orally administered the doses of 15 , 20,25 and $30 \mathrm{mg} \mathrm{kg}^{-1}$ body weight of the Escravos crude oil, respectively for 28 days. Animals in group were orally given normal saline. The different doses of the liquid Escravos crude oil were measured in weight on an electronic weighing balance (210/0.1 mg digital balance ESJ-210-4) and given orally (oral gavage) for 28 days.

\section{Animal handling and ethical approval}

The experiment was conducted in accordance with the Guidelines of the U.S. National Institute of Health (NIH Publication No. 85-23, Revised 1985) and Animal Welfare Act on the care and use of laboratory animals. All procedures were examined and approved by the Faculty of Health Science and Technology's ethics committee (ethical approval number MLS/FHST/2011346001F). The animals were kept under standard and 
good laboratory conditions (12 hour light and 12 hour darkness, temperature $\left(30{ }^{\circ} \mathrm{C} \pm 4.5\right.$ ${ }^{\circ} \mathrm{C}$ ), humidity and ventilation). Prior to exposure, the animals (rabbits) were starved overnight of solid food and their body weights taken. Their weights were also taken weekly for the duration of the study to check for weight loss or gain which is associated with toxicity. The animals were fed grower pallets (from Vital feed Ltd, Jos, Plateau State, Nigeria), vitamins and water ad libitum for 28 days.

\section{Sample collection and microscopy}

On the $29^{\text {th }}$ day (morning), the Drop method was used for anaesthesia as described by John Hopkins University Animal care and use committee (2009), using chloroform as anaesthetics given due consideration to the animals' body weights. The blood samples, obtained by marginal ear vein puncture, were aseptically drawn into tubes using 22 gauge sterile needles. For biochemical analyses, blood samples collected into plain test tubes were centrifuged (Rotofix $32 \AA-H e t t i c h$ ) at $3000 \mathrm{~g}$ for $10 \mathrm{~min}$; the serum was collected and kept at $-20{ }^{\circ} \mathrm{C}$ until analyzed. Animals were sacrificed; the testes excised, blotted dry to remove traces of blood and weighed using an electronic weighing balance (using 210/0.1 mg digital balance ESJ-210-4). The excised testes were grossed, fixed in $10 \%$ formal saline, processed through paraffin wax, sectioned and slices of $3 \mu \mathrm{m}$ thickness were stained using Haematoxylin and Eosin (H\&E) technique (Avwioro, 2002). Micrographs of the stained tissue sections were taken (by a microscope which had a camera attached to it) for comparison and documentation. The processing of the testes was carried out at the Histopathology Unit in Nnamdi Azikiwe University Teaching Hospital, Nnewi, Anambra State, Nigeria.

\section{Biochemical analysis}

Serum concentration of estradiol was determined using the microplate enzyme immunoassay kit (from MONOBIND Inc.,
USA) as described by Sood (2009). The serum total cholesterol level was estimated using the enzymatic end point method (Sood, 2009; using kit from RANDOX Laboratories, United Kingdom). Serum concentrations of the estradiol and total cholesterol were measured using ELISA machine, Mindray 96 USA, and spectrophotometer, respectively.

\section{Statistical analysis}

The values obtained from the hormonal assay, total cholesterol estimation, Change in body weight per week and organ (testis) weight were tested for homogeneity of variance and significant results were established by one-way ANOVA using the SPSS software application (version 16). Pairwise comparisons were carried out using the Post hoc test. The accepted level of significance was set at $\mathrm{p}<0.05$. The Pearson's correlation was made to correlate the serum concentrations between the estradiol and total cholesterol, with the accepted level of significance set at 0.01 .

\section{RESULTS \\ Effect on appetite}

Seven days following administration of the Escravos crude oil, the animals in the treated groups D and E lost their appetite. Considering the fact that all the groups received approximately the same amount of food, it was observed that the treated groups had reduction in food consumption (of approximately one-fourth of the entire food given per day) when compared with that consumed by the control group. In this study, significant $\quad(p<0.05)$ increase in the concentration of estradiol and total cholesterol in the serum was observed (Table 1). There was a strong positive correlation between sera concentrations of estradiol and cholesterol (Table 2). Hyperplasia and decreased spermatogenic activity were observed in the treated groups D and E (Figures 2 and 3) when compared to the control group (Figure 1). 
Table 1: Mean $( \pm \mathrm{SD})$ values of the biochemical parameters, organ and body weights of the control and treated groups.

\begin{tabular}{|c|c|c|c|c|c|c|}
\hline \multirow[t]{2}{*}{ Parameters } & \multicolumn{5}{|c|}{ Groups } & \multirow[t]{2}{*}{ P-value } \\
\hline & Group A (control) & Group B (15 mg kg $\left.{ }^{-1}\right)$ & Group C (20 mg kg $\left.{ }^{-1}\right)$ & Group D (25 mg kg $\left.{ }^{-1}\right)$ & Group E (30 $\mathrm{mg} \mathrm{kg}^{-1}$ ) & \\
\hline $\begin{array}{l}\text { Cholesterol } \\
(\mathrm{mmol} / \mathrm{l})\end{array}$ & $1.32 \pm 0.24$ & $\begin{array}{c}1.61 \pm 0.28 \\
(0.273)\end{array}$ & $\begin{array}{c}2.07 \pm 0.17 \\
(0.015)\end{array}$ & $\begin{array}{c}2.26 \pm 0.24 \\
(0.003)\end{array}$ & $\begin{array}{c}2.92 \pm 0.34 \\
(0.000)\end{array}$ & 0.001 \\
\hline $\begin{array}{l}\text { Estradiol } \\
(\mathrm{pg} / \mathrm{ml})\end{array}$ & $18.32 \pm 6.46$ & $\begin{array}{c}21.77 \pm 3.17 \\
(0.543)\end{array}$ & $\begin{array}{c}28.11 \pm 5.57 \\
(0.098)\end{array}$ & $\begin{array}{c}48.63 \pm 7.71 \\
(0.000)\end{array}$ & $\begin{array}{c}69.41 \pm 12.89 \\
(0.000)\end{array}$ & 0.000 \\
\hline $\begin{array}{l}\text { Weight of } \\
\text { Testis }(\mathrm{g})\end{array}$ & $3.80 \pm 0.40$ & $\begin{array}{c}4.40 \pm 0.80 \\
(0.345)\end{array}$ & $\begin{array}{c}5.10 \pm 0.90 \\
(0.046)\end{array}$ & $\begin{array}{c}5.30 \pm 0.90 \\
(0.019)\end{array}$ & $\begin{array}{c}5.50 \pm 0.90 \\
(0.010)\end{array}$ & 0.051 \\
\hline $\begin{array}{l}\text { Change in body } \\
\text { weight/week }(\mathrm{kg})\end{array}$ & $0.12 \pm 0.04$ & $\begin{array}{l}0.09 \pm 0.03 \\
(0.251)\end{array}$ & $\begin{array}{c}0.08 \pm 0.04 \\
(0.166)\end{array}$ & $\begin{array}{c}0.05 \pm 0.02 \\
(0.021)\end{array}$ & $\begin{array}{c}0.02 \pm 0.01 \\
(0.002)\end{array}$ & 0.019 \\
\hline Organ/Body & 31.67 & 48.87 & 63.75 & 106.00 & 275.00 & \\
\hline
\end{tabular}

weight ratio

63.75

106.00

275.00

P-value is significant at $\mathrm{p}<0.05$; The table above shows significant increase in the serum concentrations of total cholesterol and estradiol, and decrease in weight ( $<<0.05$ ) in a dose dependent manner in the treated groups. It also shows an insignificant increase in the relative weight of the testes ( $p>0.05)$ when the control group was compared with the treated groups. One-way ANOVA and Post Hoc Test.

Table 2: Correlation between the biochemical parameters within the test groups.

\begin{tabular}{lccc}
\hline Variables & r-value & p-value & Remark \\
\hline $\begin{array}{l}\text { Cholesterol correlated with } \\
\text { estradiol }\end{array}$ & $0.539 *$ & 0.014 & $\begin{array}{c}\text { Positive } \\
\text { correlation }\end{array}$
\end{tabular}

*Correlation is significant at 0.01 level (2-tailed); The table above indicates that there is a significant strong positive correlation

between the estradiol and cholesterol concentration at 0.01 level of confidence interval. From the correlation analysis, it could be adduced that the increase in serum cholesterol level lead to the increase in serum concentration of estradiol. 


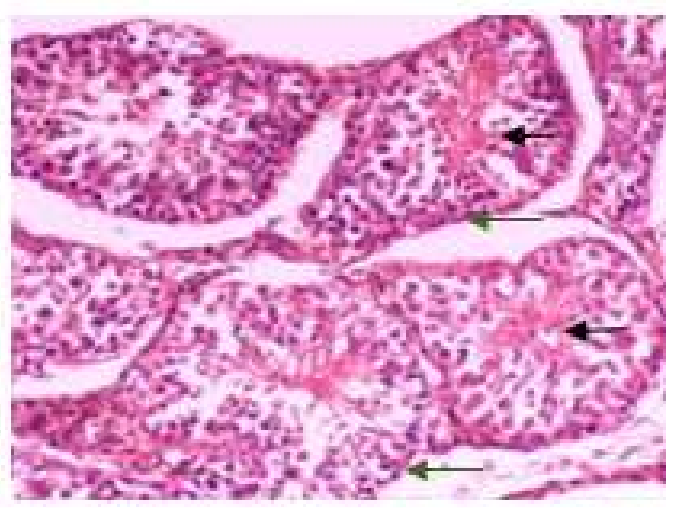

Figure 1: Control group: photomicrograph of a section of the seminiferous tubules (marked by green arrows) with normal spermatogenic activity (marked by black arrows). H\&E Stain. X200.

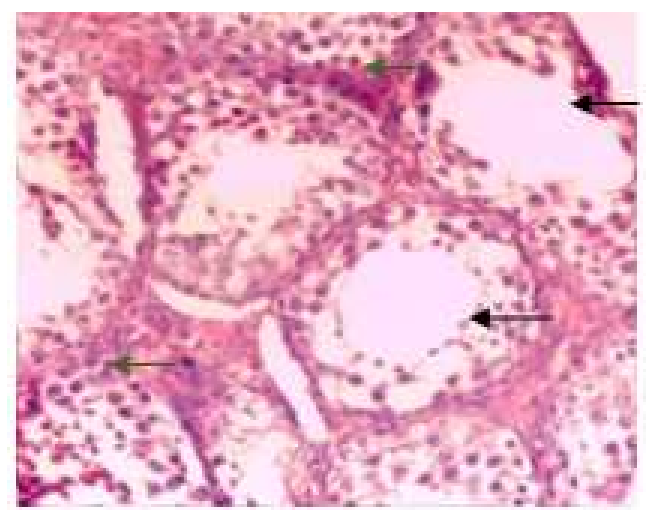

Figure 2: Group D: photomicrograph of a section of the seminiferous tubules showing hyperplasia (marked by green arrows) and decreased spermatogenic activity (black arrows). H\&E Stain X200.

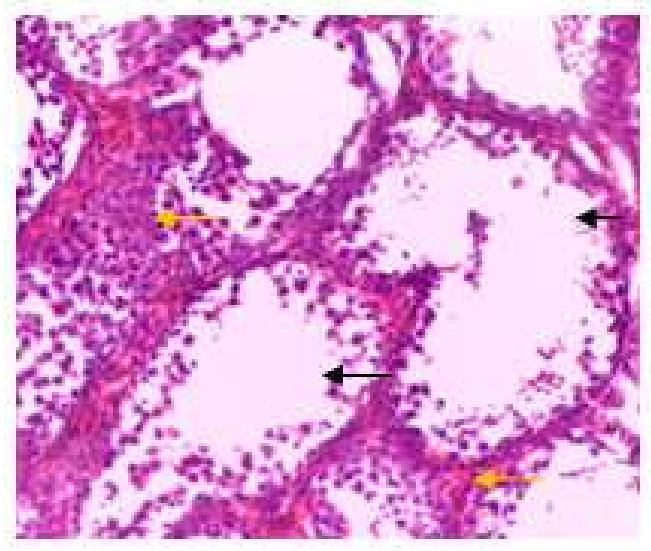

Figure 3: Group E: photomicrograph of a section of the seminiferous tubules showing hyperplasia (marked by yellow arrows) and decreased spermatogenic activity (black arrows). H\&E Stain. X200. 


\section{DISCUSSION}

Although traditionally, estradiol is considered the female sex hormone, but through a number of experimental models, it has been shown that estradiol plays a vital role in normal sperm cell development and function (O'Donnel et al., 2001; Hess, 2003; Akingbemi, 2005). Escravos crude oil has been reported to cause decreases in progesterone concentration (Okoye et al., 2014b) and increase in testosterone concentration (Afonne et al., 2013) following oral administration. In this study, significant increase in the concentration of estradiol and total cholesterol in the serum was observed (Table 1). Since there was a strong positive correlation between sera concentrations of estradiol and cholesterol (Table 2), it could be adduced that the abundance of cholesterol (which is a precursor of steroid hormones) induced by the administered Escravos crude oil may have contributed to the significant increase in estradiol production. The possible mechanism could be by increased degradation of cholesterol to progestin which may have been actively converted to testosterone and was in turn aromatized to oestrogen (estradiol). On the other hand, increase in serum concentration of estradiol could also be due to the hyperplasia of the Leydig cells (which is involved in the production of estrogen in the testes).

Some studies have provided novel insight into the molecular basis for spermiation failure and apoptosis caused by 17 beta-estradiol and also offer new mechanisms by which adult exposure to environmental estrogens can affect spermatogenesis and fertility (Balasinor, 2010). Studies on boys delivered by mothers treated with diethylstilbestrol, a very potent estrogen agonist from 1950 to 1970, have reported alterations in sperm quality and higher incidence of genital malformations, cryptorchidism, and testicular cancer compared to the control population (Strohsnitter et al., 2001). Estrogenic drugs administered by injections, oral gavage, or through drinking water have been claimed to result in varied effects such as decreased Sertoli cell number, Leydig cell hyperplasia and decreased sperm count (Oishi, 2002;
Akingbemi et al., 2004). These earlier reports lend support to the findings of this study where hyperplasia and decreased spermatogenic activity were observed in the treated groups D and E (Figures 2 and 3) when compared to the control group (Figure 1). The increase in the weight of the testis could be as a result of the hyperplasia observed in the treated groups, especially group D and E. The decreased change in body weight per week could be linked the decreased appetite observed in the treated groups, particularly groups D and E. The marked increase in organ versus body weight ratio observed in groups D and E could be adduced to the pathologic effect of Escravos crude oil on the entire body system of the experimental animals.

\section{Conclusion}

Escravos crude is suggested to possess anti-spermatogenic properties through its estrogenic effect on the testes. This effect, if not checked, could lead to infertility and possibly testicular cancer.

\section{ACKNOWLEDGEMENTS}

Authors owe a great deal of gratitude to the entire staff of Medical Laboratory Science Department (Nnamdi Azikiwe University) for their technical assistance during the study.

\section{REFERENCES}

Adesanya OA, Shittu LA, Omonigbehin EA, Tayo AO. 2009. Spermatotoxic impact of bonny light crude oil (BLCO) ingestion on adult male Swiss albino mice. Int. J. Physical Sci., 4(5): 349-353.

Afonne OJ, Onyiaorah IV, Orisakwe OE. 2013. Toxicity of Cheveron Escravos crude oil and chemical dispersant on guinea pig testicular function. J. Basic Clin. Physiol. Pharmacol., 24(4):321329.

Akingbemi BT. 2005. Estrogen regulation of testicular function. Reprod. Biol. Endocrinol., 3: 51.

Akingbemi BT, Ge R, Klinefelter GR, Zirkin BR, Hardy MP. 2004. Phthalateinduced Leydig cell hyperplasia is associated with multiple endocrine disturbances. Proc. Natl. Acad. Sci. USA., 101: 775-780. 
Avwioro OG. 2002. Histochemistry and Tissue Pathology Principles and Techniques, ( $1^{\text {st }}$ edn). Ibadan Nigeria; 154-162.

Balasinor NH, D'Souza1 R, Nanaware P, Idicula-Thomas S, Kedia-Mokashi N, He Z, Dym M. 2010. Effect of high intratesticular estrogen on global gene expression and testicular cell number in rats. Reprod. Biol. Endocrinol., 8: 72-86.

Dede EB, Igboh NM, Ayalogu OA. 2002. Chronic study of crude petroleum bonny light, kerosene, and gasoline using haematological parameters. J. Appl. Sci. Environ. Managt., 6(1): 60-66.

Delbes G, Levacher C, Habert R. 2006. Estrogen effects on fetal and neonatal testicular development. Reprod., 132: 527-538.

Eyong EU, Umoh IB, Ebong PE, Eteng MV, Anatai AB, Akpa AO. 2004. Haematoxic Effects Following Ingestion of Nigerian Crude Oil and Crude Oil Polluted Shellfish by rats. Nig. J. Physiol. Studies, 19(1-2): $1-6$.

Hess RA. 2003. Estrogen in the adult male reproductive tract: a review. Reprod. Biol. Endocrinol., 1: 52.

John Hopkins University (JHU). 2009. Animal care and use committee; Drop method, JHU, 1-2.

Morrissey J. 2006. Cholesterol and steroid metabolism. Med. Biochem ( $3^{\text {rd }}$ edn). Lipinncott: UK; 368-372.

Neff JM, Ostazeski S, Gardiner W, Stejskal I. 2000. Effects of weathering on the toxicity of three offshore Australian crude oils and a diesel fuel to marine animals. Environ. Toxicol. Chem., 19: 1809-1821.

Ngokere AA, Okoye JO, Ogenyi SI, Bukar SM, Ude T. 2014. Histopathological and biochemical disrupting effects of Escravos crude oil on the liver and heart in Chinchilla rabbits. Afr. J. Environ. Sci. Technol., 8(3): 203-209.

Nwilo PC, Badejo OT. 2005. Oil spill problems and management in the Niger
Delta. International Oil Spill Conference. Miami, Florida, USA. Euro. J. Sci. Res. 52(4): 592-603.

O'Donnell L, Robertson KM, Jones ME, Simpson ER. 2001. Estrogen and spermatogenesis. Endocr. Rev., 22: 289318.

Oishi S. 2002. Effects of propyl paraben on the male reproductive system. Food Chem. Toxicol., 40: 1807-1813.

Okoye JO, Ngokere AA, Okeke CO. 2014a. Biochemical, haematological and histological effects following Escravos crude oil ingestion by Chinchilla rabbits. Int. J. Med. Med. Sci., 6(2): 63-68.

Okoye JO, Ngokere AA, Ogenyi SI, Onyemelukwe AO. 2014b. Histopathological and hormonal disrupting effects of Escravos crude oil on the ovary of Chinchilla rabbits. $J$. Toxicol. Eniviron. Health Sci., 6(2): 3137.

Otitoju O, Onwurah INE, Otitoju GTO, Ndem JI, Uwah AF. 2011. Effect of Bonny light crude oil contaminated diet on serum cholesterol and testosterone concentrations in Wistar albino rats. Afr. J. Biotechnol., 10(53): 10986-10990.

Pentikainen V, Erkkila K, Suomalainen L, Parvinen M, Dunkel L. 2000. Estradiol acts as a germ cell survival factor in the human testis in vitro. J. Clin. Endocrinol. Metab., 85: 2057-2067.

Sood R. 2009. Medical Laboratory Technology Method and Interpretations, $\left(6^{\text {th }}\right.$ edn, vol 2). Jaypee Brothers Medical Publishers (P) LTD: New Delhi.

Strohsnitter WC, Noller KL, Hoover RN, Robboy SJ, Palmer JR, Titus-Ernstoff L, Kaufman RH, Adam E, Herbst AL, Hatch EE. 2001. Cancer risk in men exposed in utero to diethylstilbestrol. J. Natl. Cancer Inst., 93: 545-551. 